\title{
Causes of death in osteogenesis imperfecta
}

\author{
Susan J McAllion, Colin R Paterson
}

\begin{abstract}
Aims-To determine the causes of death in patients with osteogenesis imperfecta, excluding infants with the perinatal lethal form (type II).

Methods-Seventy nine patients with known osteogenesis imperfecta were identified, 37 of whom had been seen clinically in life. Causes of death were identified from death certificates, postmortem reports, medical records, hospital consultants, relatives, and the Brittle Bone Society's records.

Results-Patients with the milder types of osteogenesis imperfecta, I and IV, often had a normal lifespan and died of unrelated illnesses such as myocardial infarction and malignancy. In some of these patients and in many patients with the more severe type III disease, it was clear that osteogenesis imperfecta contributed significantly to death, almost certainly to many of the respiratory deaths and to deaths from cardiac failure due to kyphoscoliosis. Osteogenesis imperfecta also caused six deaths, directly or indirectly, due to basilar invagination of the skull. Osteogenesis imperfecta may have contributed to deaths from intracranial bleeding. Apparently minor traumatic incidents may have disastrous consequences in patients with this disorder.

Conclusions-Prompt care for respiratory infections and prevention of trauma in patients with osteogenesis imperfecta is essential.

(F Clin Pathol 1996;49:627-630)
\end{abstract}

Keywords: osteogenesis imperfecta, causes of death, pneumonia, trauma.

Osteogenesis imperfecta is a group of congenital disorders causing fractures. Almost all are thought to be caused by defects of collagen synthesis. It is genetically heterogeneous. Many cases are inherited in an autosomal dominant manner; new mutations are frequent. A few result from autosomal recessive inheritance. Some result from parental mosaicism and in many sporadic cases the genetic cause is unclear. Sillence $e t a^{1}{ }^{2}$ devised the widely used classification into four types (table 1). It is important to recognise that within each clinical type there is great heterogeneity; at a molecular level almost all families have unique mutations. $^{3}$

Little has been published on the causes of death in osteogenesis imperfecta. Vetter et $a l^{4}$ studied 127 children during the first 10 years of life. During the study, five type III patients with instability of the thorax died with respiratory failure and staphylococcal pneumonia. One type IV patient died because of primary pulmonary hypertension.

Wynne-Davies and Gormley ${ }^{5}$ reported a survey of 101 patients with osteogenesis imperfecta carried out between 1974 and 1979. Of these, 19 patients died. There were seven deaths in children under five years of age, six due to respiratory insufficiency and one due to a strangulated inguinal hernia. Of the 12 older patients, five died of bronchopneumonia, two from neurosurgical complications related to basilar invagination, two from aortic aneurysm, one from a perforated peptic ulcer, one from osteosarcoma, and one suicide. However, the patients were not classified by clinical type.

\section{Methods}

Sixty eight cases were obtained as part of the large survey described previously ${ }^{6-8}$; this survey now includes 1297 patients ascertained between 1980 and 1995. Of the 68 who died, 37 had been examined clinically by one of us in life. An additional 11 patients, not otherwise known to us, were identified by the Office of Population, Censuses and Survey (OPCS) which provided copies of death certificates. These certificates gave information about each patient's name, date of birth and place of death; we were therefore able to obtain hospital records on many of these patients. The terms of the agreement with the OPCS precluded any contact with the families of these patients.

Each patient was classified on clinical grounds according to the Sillence scheme. In some of the patients ascertained only through the OPCS it was not possible to determine from the hospital records whether they had the type I or type IV disorder. Patients with the perinatal lethal form of osteogenesis imperfecta (type II) were excluded. Information was then collected on date of birth, date of death and cause of death. Information was obtained 
Table 1 Classification of osteogenesis imperfecta ${ }^{12}$

\begin{tabular}{lll}
\hline $\begin{array}{l}\text { Sillence } \\
\text { type }\end{array}$ & Clinical features & Inheritance \\
\hline I $^{\star}$ & $\begin{array}{l}\text { Mild to moderate severity. Little } \\
\text { impairment of growth. Sclerae blue at all } \\
\text { ages. }\end{array}$ & $\begin{array}{l}\text { Autosomal dominant. New mutations } \\
\text { occur frequently. }\end{array}$ \\
II & $\begin{array}{l}\text { Very severe disease causing stillbirth or } \\
\text { early neonatal death. }\end{array}$ & $\begin{array}{l}\text { New dominant mutation. Parental } \\
\text { mosaicism. }\end{array}$ \\
III & $\begin{array}{l}\text { Severe disease with antenatal fractures in } \\
\text { most cases. Progressive deformity } \\
\text { common. Severe impairment of growth. }\end{array}$ & $\begin{array}{l}\text { New dominant mutation. Parental } \\
\text { mosaicism. Autosomal recessive. }\end{array}$ \\
& $\begin{array}{l}\text { Sclerae blue in some but not all cases. } \\
\text { Dentinogenesis imperfecta common. } \\
\text { IV }\end{array}$ & $\begin{array}{l}\text { Mild to moderate severity. Impairment of } \\
\text { growth may occur. White sclerae in older } \\
\text { children and adults; pale blue sclerae in } \\
\text { early childhood. }\end{array}$ \\
\hline
\end{tabular}

^Subdivided into A (no overt dental abnormality) and B (dentinogenesis imperfecta present).

Table 2 Causes of death in 79 patients with osteogenesis imperfecta

\begin{tabular}{|c|c|c|c|c|}
\hline Cause of death & $\begin{array}{l}\text { ICD } 10 \\
\text { code }\end{array}$ & Type III & Types I and IV & Total \\
\hline Adenocarcinoma of pancreas & C25.9 & & 1 & 1 \\
\hline Carcinoma of prostate & C61 & & 1 & 1 \\
\hline Carcinoma (primary unknown) & $\mathrm{C} 80$ & & 1 & 1 \\
\hline Motor neurone disease & G12.2 & & 1 & 1 \\
\hline Muscular dystrophy & G71.2 & & 1 & 1 \\
\hline Compression of brain & G93 & & 3 & 3 \\
\hline Myocardial infarction & 121.9 & & 6 & 6 \\
\hline Coronary artery disease & I25.1 & & 2 & 2 \\
\hline Pulmonary embolism & I26.9 & & 1 & 1 \\
\hline Kyphoscoliotic heart disease & I27.1 & 1 & 1 & 2 \\
\hline Mitral regurgitation & $\mathrm{I} 34$ & & 1 & 1 \\
\hline Subarachnoid haemorrhage & I60.9 & & 2 & 2 \\
\hline Intracerebral haemorrhage & I61.9 & & 2 & 2 \\
\hline Epiglottitis & J05.1 & 1 & & 1 \\
\hline Viral bronchopneumonia & $\mathrm{J} 12$ & 1 & & 1 \\
\hline Bronchopneumonia & J18.0 & 9 & 6 & 15 \\
\hline Hypostatic pneumonia & $\mathrm{J} 18.2$ & 1 & 5 & 6 \\
\hline Pneumonia & J18.9 & 8 & & 8 \\
\hline Bronchitis & $\mathrm{J} 20$ & 1 & & 1 \\
\hline Bronchiolitis & $\mathrm{J} 21$ & 1 & & 1 \\
\hline Chest infection & $\mathrm{J} 22$ & 8 & 2 & 10 \\
\hline Aspiration pneumonia & $\mathrm{J} 69$ & & 1 & 1 \\
\hline Acute respiratory failure & $\mathrm{J} 96.0$ & & 1 & 1 \\
\hline Chronic respiratory failure & J96.1 & & 1 & 1 \\
\hline Peritonitis $^{\star}$ & K57.2 & & 1 & 1 \\
\hline Septicaemia & O08.0 & 1 & & 1 \\
\hline Cardiorespiratory failure & R09.2 & 1 & & 1 \\
\hline Traumatic cerebral haemorrhage & S06.3 & 1 & & 1 \\
\hline Extradural haemorrhage & S06.4 & 1 & & 1 \\
\hline Multiple head injuries & S09.7 & 2 & & 2 \\
\hline Pulmonary fat embolism & T79.1 & & 1 & 1 \\
\hline Road traffic accident & V49.9 & 1 & & 1 \\
\hline Total & & 38 & 41 & 79 \\
\hline
\end{tabular}

^Peritonitis due to perforated colonic diverticulum.

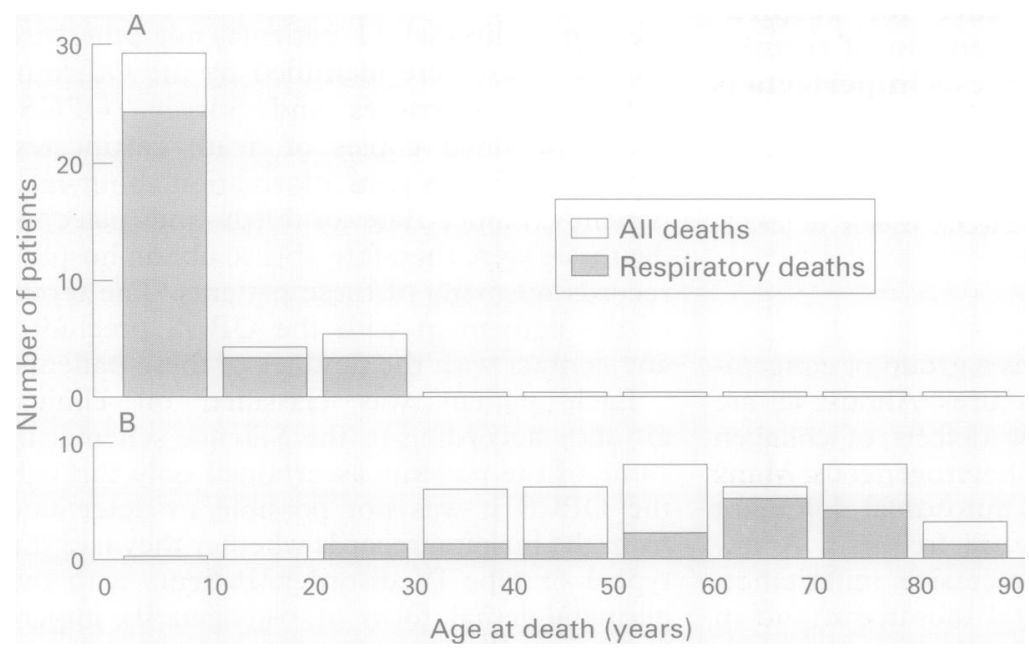

Figure 1 Age at death in 79 patients with osteogenesis imperfecta subdivided into $(A)$ type III (progressive deforming type) and (B) types I and IV (mild to moderate types). from death certificates, postmortem reports, medical records, hospital consultants, relatives, and the Brittle Bone Society. The causes of death were then coded by the ICD 10 c classification. $^{9}$

\section{Results}

In the whole group the age at death varied widely (table 2 ). However, when the patients were subdivided between type III and types I and IV a clear distinction was seen (fig 1). By far the most common causes of death were respiratory problems; these too show a clear distinction in age at death in relation to the clinical type of osteogenesis imperfecta.

RESPIRATORY CAUSES OF DEATH

The principal cause of death was respiratory in 46 patients; 23 had bronchopneumonia or pneumonia, six had hypostatic pneumonia and in 10 death was attributed simply to "chest infection". There was one case each of epiglottitis (a four year old boy), viral bronchopneumonia (a one year old girl), bronchitis, 으 bronchiolitis, aspiration pneumonia (a 44 year $\rightarrow$ old woman who inhaled a peanut), acute respiratory failure, and chronic respiratory failure (a 45 year old man with severe kyphoscoliosis).

Of the 42 patients with pneumonia, "chest $\vec{\theta}$ infection", bronchitis and bronchiolitis, there \%ั were 29 with osteogenesis imperfecta type III (mean age at death 6.2 years, range $1-28$ years) and 13 with types I and IV (mean age at death 63.5 years, range $22-80$ years). Among the type III patients contributory causes of death included multiple rib fractures (one case), scoliosis (one case), renal failure (one case), restrictive lung disease (one case), and cardiac failure (two cases). Among the patients with osteogenesis imperfecta types I and IV contributory causes included compression of the medulla (one case) and invagination of the skull (one case). Hypostatic pneumonia was thought to be caused by immobility in two cases and by fractures in two.

\section{CARDIOVASCULAR CAUSES OF DEATH}

The series included six patients with myocar- O dial infarction. All were males with osteogen- N esis imperfecta type I and their mean age at $\mathrm{C}^{-}$ death was 56.8 years (range $48-70$ years). In 0 two additional patients death was ascribed to 0 coronary artery disease (one female with type I $\stackrel{\mathbb{D}}{\overparen{D}}$ and one male with type IV); both had ? developed cardiac failure. In the male this caused a road traffic accident. Two patients (a one year old child with type III and a man aged 52 with type IB) died from kyphoscoliotic a heart disease. Four patients died from cerebrovascular disease: two from subarachnoid haemorrhage and two from other spontaneous intracranial bleeding without known trauma.

NEUROLOGICAL CAUSES OF DEATH

Five patients died directly of neurological problems. A 71 year old woman with type IA died of motor neurone disease and a boy with type IA died at the age of 16 with Duchenne muscular dystrophy. In the remaining three 
Table 3 Patients dying directly or indirectly from compression of brain

\begin{tabular}{|c|c|c|c|}
\hline $\begin{array}{l}\text { Age at death } \\
\text { (years) }\end{array}$ & Sex & $\begin{array}{l}\text { Osteogenesis } \\
\text { imperfecta type }\end{array}$ & Comments \\
\hline 48 & $\mathrm{~F}$ & IVB & $\begin{array}{l}\text { Headaches, nystagmus, fasciculation of left side of tongue. } x \text { ray: gross basilar } \\
\text { invagination, brain stem elongated and behind C2. Pons thinned and indented. Died } 11 \\
\text { days after transoral decompression. Necropsy: longstanding ishaemic damage to lower } \\
\text { brain stem, cerebellum and upper spinal cord. }\end{array}$ \\
\hline 40 & $\mathbf{M}$ & IVB & $\begin{array}{l}\text { Longstanding basilar invagination and chronic hydrocephalus. Respiratory arrest due to } \\
\text { brain stem herniation while in hopsital with fractured femur. }\end{array}$ \\
\hline 30 & $\mathbf{M}$ & I or IV & $\begin{array}{l}\text { Diplopia on coughing or laughing from age } 27 \text {. Transient loss of consciousness. } \\
\text { Decompression surgery left him quadriplegic and aphasic. Died } 2.5 \text { years later. }\end{array}$ \\
\hline 38 & $\mathrm{~F}$ & I or IV & $\begin{array}{l}\text { Died of bronchopneumonia; compression of medulla a contributory cause. No other } \\
\text { information available. }\end{array}$ \\
\hline 22 & $\mathrm{~F}$ & IVA & $\begin{array}{l}\text { Weakness of right hand, wasting of left side of tongue and left facial numbness. Surgery } \\
\text { contraindicated because of very poor respiratory reserve. Died of chest infection. }\end{array}$ \\
\hline 23 & $\mathrm{~F}$ & III & $\begin{array}{l}\text { Severe basilar invagination with medullary compression, very poor vital capacity and low } \\
\text { tidal volume. Decompression with removal of clivus, } \mathrm{Cl} \text { and } \mathrm{C} 2 \text {. Initially did well } \\
\text { despite chest infections. Died of septicaemia eventually traced to uterine infection } \\
\text { following termination of pregnancy four weeks before surgery. }\end{array}$ \\
\hline
\end{tabular}

Table 4 Traumatic causes of death in patients with osteogenesis imperfecta

\begin{tabular}{|c|c|c|c|}
\hline $\begin{array}{l}\text { Age at death } \\
\text { (years) }\end{array}$ & Sex & $\begin{array}{l}\text { Osteogenesis } \\
\text { imperfecta type }\end{array}$ & Comments \\
\hline 15 & M & III & $\begin{array}{l}\text { Was being towed in his wheelchair behind his brother's bicycle. The wheelchair swerved } \\
\text { into the path of a van. He fractured all limbs but cause of death was cerebral } \\
\text { haemorrhage due to skull fracture with severe coronary disease a contributory cause. }\end{array}$ \\
\hline 20 & $\mathbf{F}$ & III & $\begin{array}{l}\text { Back seat passenger in road traffic accident. Fracture of humerus, femora and sternum. } \\
\text { Oedema and contusion of lungs. Cause of death was multiple head injuries including } \\
\text { fracture of orbital plates and subarachnoid haemorrhage. }\end{array}$ \\
\hline 28 & $\mathbf{F}$ & III & No information other than that she died in a road traffic accident. \\
\hline 9 & $\mathrm{M}$ & III & $\begin{array}{l}\text { Fell forward from wheelchair at school. Not strapped in. Fractured arm; seen in hospital. } \\
\text { Head injury not recognised. Declined over six hours. Readmitted and found to have } \\
\text { fractured skull and extradural bleeding. }\end{array}$ \\
\hline 9 & $\mathrm{~F}$ & III & $\begin{array}{l}\text { Slipped out of wheel chair having undone her straps in preparation for being carried } \\
\text { upstairs. Bilateral femur fractures, skull fracture, extradural and subdural bleeding. }\end{array}$ \\
\hline 13 & $\mathbf{M}$ & IVB & $\begin{array}{l}\text { Was being pushed in wheelchair at school. Not strapped in. Front wheel stuck in uneven } \\
\text { ground, propelling him forward. Fractures of both tibiae and both humeri, leading to } \\
\text { pulmonary fat embolism. }\end{array}$ \\
\hline
\end{tabular}

patients the principal cause of death was compression of the brain due to basilar invagination. In three additional patients this was a significant contributory factor (table 3).

\section{TRAUMATIC CAUSES OF DEATH}

The details of the six patients in this group are given in table 4 .

\section{Discussion}

While the number of patients dying with osteogenesis imperfecta is too small to permit a formal statistical comparison with the general population, we were able to contrast our findings with the general population in terms of the proportion of deaths with each cause (table 5). Expressed in this way, the significance of respiratory disease, particularly in the severe (type III) disorder, is emphasised. In these patients it is likely that the chest deformity and scoliosis contribute to the limitation of thoracic function. In two cases multiple rib fractures were thought to have been a factor.

Of the patients who died of a cardiovascular cause, the number with coronary disease was probably no more than would be expected in the general population; the number is too small for any formal analysis. In the two with kyphoscoliotic heart disease it is likely that osteogenesis imperfecta was the major underlying factor. While problems with the cardiac valves, particularly aortic and mitral incompetence, are recognised in osteogenesis imperfecta, ${ }^{11}$ we had only one patient in whom mitral incompe- tence contributed to death. The four patients with spontaneous intracranial bleeding may be more than would be expected in the general population. Individual patients who had intracranial bleeding with no trauma or trivial trauma have been reported. ${ }^{12-15}$ Increased liability to bruising and other bleeding problems are well recognised in patients with osteogenesis imperfecta; the most significant cause is thought to be vascular fragility related to collagen defects. ${ }^{16} 17$

In six patients death was caused directly or indirectly by basilar invagination and compression of the brain stem. This problem can lead to sudden death because of pressure on the respiratory centre. ${ }^{18}$ This may be prevented by decompression surgery, which is not without risk in this group of patients who may have very limited respiratory reserves.

Of the six patients who died following trauma, three had fallen from wheelchairs. The relatively minor falls would probably not have caused difficulties in patients without osteo-

Table 5 Causes of death in osteogenesis imperfecta: comparison with the general population. ${ }^{10}$ Deaths from each group of causes are expressed as percentages of all deaths

\begin{tabular}{lccc}
\hline & \multicolumn{2}{l}{$\begin{array}{l}\text { Osteogenesis } \\
\text { imperfecta type }\end{array}$} & \\
\cline { 2 - 3 } Cause of death & III & I and IV & General population \\
\hline Respiratory & 81.6 & 39.0 & 15.7 \\
Cardiovascular & 2.6 & 36.6 & 44.6 \\
Neurological & 0 & 12.2 & 1.6 \\
Trauma & 13.2 & 2.4 & 2.7 \\
Other & 2.6 & 9.8 & 35.4 \\
\hline
\end{tabular}


genesis imperfecta. In the two with traumatic intracranial bleeding, the vascular fragility discussed earlier may have contributed. These cases emphasise the importance of wearing seat belts in wheelchairs.

Our findings emphasise the danger of early death in patients with osteogenesis imperfecta type III. In contrast patients with the milder forms, types I and IV, may have a normal lifespan and die of unrelated illnesses such as myocardial infarction and malignancy. In a complementary study $^{19}$ we showed that life expectancy in patients with type IA was indistinguishable from that in the general population, only marginally impaired in a composite group consisting of types IB, IVA and IVB and significantly impaired in the type III disease.

Our survey showed that osteogenesis imperfecta contributed significantly to death in some patients, particularly those with the type III disease. It clearly played a part in many of the respiratory deaths and in deaths from cardiac failure due to kyphoscoliosis. Osteogenesis imperfecta also caused six deaths, directly or indirectly, due to basilar invagination of the skull. Osteogenesis imperfecta may have contributed to deaths from intracranial bleeding. Apparently minor traumatic incidents may have disastrous consequences in patients with this disorder. We emphasise the importance of prompt care for respiratory infections and of the prevention of trauma.

For help with the data collection we are indebted to Mrs Elizabeth Monk
1 Sillence DO, Senn A, Danks DM. Genetic heterogeneity in osteogenesis imperfecta. $\mathcal{f}$ Med Genet 1979;16:101-6.

2 Sillence DO. Osteogenesis imperfecta: an expanding panorama of variants. Clin Orthop 1981;159:11-25.

3 Byers $\mathrm{PH}$, Wallis GA, Willing MC. Osteogenesis imperfecta: translation of mutation to phenotype 7 Med Genet 1991;28:433-42.

4 Vetter U, Pontz B, Zainer E, Brenner RE, Spranger J. Osteogenesis imperfecta: a clinical study of the first 10 years of life. Calcif Tissue Int 1992;50:36-41.

5 Wynne-Davies R, Gormley J. Clincal and genetic patterns in osteogenesis imperfecta. Clin Orthop 1981;159:26-35.

6 Paterson CR, McAllion S, Miller R. Heterogeneity of osteogenesis imperfecta type I. f Med Genet 1983;20:203-5.

7 Paterson CR, McAllion S, Miller R. Osteogenesis imperfecta with dominant inheritance and normal sclerae. $\mathcal{f}$ Bone foint Surg Br 1983;65:35-9.

8 Paterson CR, McAllion SJ, Shaw JW. Clinical and radiological features of osteogenesis imperfecta type IVA. Acta Paediatr Scand 1987;76:548-52.

9 World Health Organisation. International Statistical Classification of Diseases and Related Health Problems. Tenth revision. Geneva: World Health Organisation, 1992.

10 Office of Population Censuses and Surveys. Mortality Statistics 1993: Cause (Series DH2 no 20) London: HMSO, 1995.

11 White NJ, Winearls CG, Smith R. Cardiovascular abnormalities in osteogenesis imperfecta. Am Heart $\mathcal{f} 1983$; 106: 1416-20.

12 Pozzati E, Poppi M, Gaist G. Acute bilateral hematomas in a case of osteogenesis imperfecta congenita. Neurosurgery 1983;13:66-8.

13 Diaz LA, Lippe K. Acute extradural hematoma following $N$ trivial trauma in a case of osteogenesis imperfecta. Neurochirurgia 1985;28:180-1.

14 Sayre MR, Roberge RJ, Evans TC. Nontraumatic subdural hematoma in a patient with osteogenesis imperfecta and renal failure. Am 7 Emerg Med 1987;5:298-301.

15 Tokoro $\mathrm{K}$, Nakajima $\mathrm{F}$, Yamataki A. Infantile chronic subdural hematoma with local protrusion of the skull in a case of osteogenesis imperfecta. Neurosurgery 1988; 22:595-8.

16 Evensen SA, Myhre L, Stormorken H. Hemostatic studies in osteogenesis imperfecta. Scand $\mathcal{f}$ Haematol 1984; 33:177-9.

17 Khalil MK Subhyaloid hemorrhage in osteogenesis imperfecta tarda. Can 7 Ophthalmol 1983;18:251-2.

18 Charnas LR, Marini JC. Communicating hydrocephalus, basilar invagination and other neurological features in basilar invagination and other neurological featur
osteogenesis imperfecta. Neurology 1993;43:2603-8.

19 Paterson CR, Ogston S, Henry RM. Life expectancy in osteogenesis imperfecta. BMF 1996;312:351. 